IRSH 65 (2020), pp. 93-I Is doi:I0.1017/S0020859020000I03

(C) 2020 Internationaal Instituut voor Sociale Geschiedenis. This is an Open Access article, distributed under the terms of the Creative Commons Attribution licence (http:// creativecommons.org/licenses/by/4.0/), which permits unrestricted re-use, distribution, and reproduction in any medium, provided the original work is properly cited.

\title{
Freedom of Movement, Access to the Urban Centres, and Abolition of Slavery in the French Caribbean
}

\author{
MARION PLUSKOTA \\ Institute for History, Leiden University \\ Johan Huizinga, Doelensteeg I6, \\ 23 I VL Leiden, The Netherlands \\ E-mail: m.pluskota@hum.leidenuniv.nl
}

\begin{abstract}
How did the abolition of slavery influence the relations between urban centres and rural areas? How did "new" French citizens experience access to the urban environment? Based on the archives of the correctional courts, this article focuses on how race and citizenship determined the accessibility of French colonial urban spaces and institutions after I848. The abolition of slavery in the French Antilles on 27 April I 848 led to a modification of the legal and judicial systems: the changing legal status of former slaves gave them new opportunities to move around the colonies, at least on paper. In theory, after I 848 , everyone should have had freedom of social and spatial mobility and access to the urban centres and their institutions; what happened in practice, however, still needs to be researched. This article shows that the abolition exacerbated two dynamics already at play since the beginning of the nineteenth century: the control of the population and the attraction of the urban environment for the elite. The plantation system in the mid-nineteenth century was suffering both economically and politically: the newly acquired freedom and possible migration of former slaves to the towns (Saint-Pierre and Fort-de-France in Martinique, Pointe-à-Pitre and Basse-Terre in Guadeloupe) threatened to destabilize the system of private justice as well as the economic apparatus. To counteract these legal changes, vagrancy laws were implemented to restrict citizens' mobility while, at the same time, the white elite's discourse on urban spaces changed from them being seen as a hotbed for revolutionary ideas to representing a safe environment to which access needed to be restricted.
\end{abstract}

\section{INTRODUCTION}

Controlling, and criminalizing if necessary, the mobility of colonial subjects was an early priority for early modern colonial authorities. The colonies 
had been used as a safety valve by some states, such as Portugal and the UK, to send vagrants from Europe to work, and labour shortage dictated where they were to be sent. ${ }^{\mathrm{I}}$ The idea that colonial subjects could move where and when they chose was greatly undermined by the eighteenth century. Sarah Nicolazzo has shown how, in the eighteenth century, vagrancy took on a new meaning in the British colonies as labour became an essential value to the developing economy. ${ }^{2}$ Vagrancy acts, originally copied from the metropoles, multiplied in the colonies to meet various purposes. The authorities used vagrancy laws to: control work supply; supervise the population; prevent the use of "non-conformist culture" such as obeah; ${ }^{3}$ and as a form of social control to "improve" the nature of the population living in these territories. Some historians have suggested that, before emancipation and abolition, vagrancy laws were mostly aimed at "undesirable" Europeans, who were not carrying their weight in the development of the colony. ${ }^{4}$ In port cities such as Calcutta and Zanzibar, vagrancy acts were used to get rid of drunk and disorderly Europeans, who were seen as a bad influence to the local communities whose labour was essential for economic development. ${ }^{5}$ The means for sanctions against these subjects were however limited: it was not always possible to make them leave the colony, especially if they had been sent there as a punishment for vagrancy from their home country. In the nineteenth century and from the emancipation era onwards, vagrancy laws became a tool to force freed people to work in colonies relying mostly on an agricultural economy: studies on South African legislations against vagrants during the emancipation or on the West Indian British colonies and the United States after the civil war have shown how vagrancy laws were used to prevent freed people's mobility. ${ }^{6}$ Vagrancy acts in the Caribbean colonies have often been seen as distinct from

I. A.L. Bier and Paul Ocobock (ed.), Cast Out: Vagrancy and Homelessness in Global and Historical Perspectives (Athens, OH, 2008), pp. I 2-1 3; Muiris MacGiollabhui, "'Carrying the Green Bough': The Transnational Exile of the United Irishman, I79I-I 806”, in Thomas Adam (ed.), Yearbook of Transnational History, vol. 2 (Vancouver, 2019), pp. 51-76, 57.

2. Sarah Nicolazzo, "Vagrant Figures: Law, Labor, and Refusal in the Eighteenth-Century Atlantic World” (Ph.D., Penn University, 20I4). Available at: http://repository.upenn.edu/edissertations/r 386; last accessed i November 2019.

3. Danielle Boaz, "Fraud, Vagrancy and the Pretended Exercise of Supernatural Powers in England, South Africa and Jamaica”, Law and History, 5: (2018), pp. 54-84; Danielle N. Boaz, "Obeah, Vagrancy, and the Boundaries of Religious Freedom: Analyzing the Proscription of 'Pretending to Possess Supernatural Powers' in the Anglophone Caribbean", Journal of Law and Religion, 32 (2017), pp. 423-448.

4. Bier and Ocobock, Cast Out, p. I 3 .

5. Ibid.

6. Richard Lyess Watson, Slave Emancipation and Racial Attitudes in Nineteenth-Century South Africa (Cambridge, 20I2), pp. 48-50; Elizabeth Elbourne, "Freedom at Issue: Vagrancy Legislation and the Meaning of Freedom in Britain and the Cape Colony, 1799 to I 842 ", Slavery E Abolition, Is (1994), pp. I I4-1 so; Richard K. Fleischman, David Oldroyd, and Thomas N. Tyson, "The Efficacy/Inefficacy of Accounting in Controlling Labour During the Transition 
legislations and practices against marronage; however, as suggested by Robert Bancroft Cummings, ${ }^{7}$ the distinction between the two is more subtle than initially thought. Before the nineteenth century, policing of vagrancy and marronage was carried out by masters and civilians, as were the punishments against runaway slaves. Control was thus exercised first and foremost by the plantation owners and their intendants, with help, if possible, of the local authorities. The ad hoc construction of justice in the colonies, especially in the British and French Caribbean colonies, which followed a proto-national model of development, meant that discretion on the side of the prosecutors was relatively large. Nicolazzo demonstrates how, in the eighteenth century, the "unpredictable mobility" of certain people, not easily identifiable, became synonymous with social and economic threats and therefore justified the extension of policing powers, as did marronage. ${ }^{8}$ Viola Müller argues in this Special Issue that a more nuanced understanding of marronage is necessary to fathom the reality experienced by runaway slaves. Likewise, this article on vagrancy in the French colonies argues that the study of vagrancy acts against the new French citizens reveals more than a willingness by the local elite to prevent the mobility of the workforce. It highlights their attempts to create white urban enclaves by limiting access to the urban territory and urban institutions by freed people. The premises of racial segregation and urbanization control in colonial cities, which have usually been studied from the perspective of British colonies, ${ }^{9}$ appear to have been well established in the agricultural colonies of the French Caribbean.

In theory, everyone after 1848 should have had freedom of social and spatial mobility and access to the judicial system and the urban market; but what happened in practice still needs to be researched. The question of former slaves' mobility has never been framed by historians of the French Caribbean in relation to the changing perception of the urban environment in a predominantly agricultural system. How did these legal changes impact freemen and freewomen and former slaves' access to the urban environment? The changing legal status of former slaves gave them new opportunities to move around the colonies, at least on paper. And having access to the urban environment also meant having access to the highest institutions of the colonies, particularly the courts of justice. Based on the archives of the

from Slavery in the United States and British West Indies", Accounting, Auditing \& Accountability Journal, 24 (20II), pp. 75 I -780.

7. Robert Bancroft Cummings, “Queer Marronage and Caribbean Writing” (Ph.D., Leeds University, 201 2), p. 46.

8. Nicolazzo, "Vagrant Figures", p. 35.

9. Andrew Burton, African Underclass: Urbanisation, Crime and Colonial Order in Dar es Salaam (Oxford, 2005), pp. I6-23; Jocelyn Alexander, "Hooligans, Spivs and Loafers"?: The Politics of Vagrancy in 1960 S Southern Rhodesia", The Journal of African History, 53 (2012), pp. $345-366,346-347$. 
correctional courts, this article focuses on how race and citizenship ${ }^{10}$ determined the accessibility of French colonial urban spaces and institutions after i 848 .

\section{URBANIZATION IN THE FRENCH ANTILLES}

The development of the sugar economy in the French Caribbean territories since the seventeenth century led to a relatively high population density in the most favourable islands. ${ }^{I}$ Calm bays such as Fort-Royal (now Fort-deFrance) and Saint-Pierre in Martinique, Port-au-Prince and Cap-Français in Haiti, or Basse-Terre and Pointe-à-Pitre in Guadeloupe became important ports of commerce, growing thanks to the colonial trades of, among others, slaves, sugar, indigo, and cotton. ${ }^{{ }^{2}}$ These towns, which developed out of the port and/or military defences, followed an orthogonal street plan, often bordered by drainage canals or rivers, as in Fort-de-France, creating "natural" borders to the urban enclaves. ${ }^{13}$ Saint-Pierre was surrounded by volcanic slopes that prevented its development towards the east and was also crossed by a river on its northern side (Figure I). ${ }^{14}$ These canals, rivers, and hills became a border between the colonial town and the faubourgs, which grew in connection with the port economy, but were not yet subject to urban planning. ${ }^{\text {Is }}$ Other French settlements of military origins in the Caribbean remained relatively small, such as Marigot in Saint Martin or Cayenne in French Guyana. ${ }^{16}$ Despite being a strong contender in the eighteenth-century slave trade, with more than 500,000 men and women being transported to the French Antilles, the French settlements experienced limited urban development until the nineteenth century. Small parishes or bourgs were, however,

ı. "Citizen" in this article refers to a person with civil rights, not political rights. On the possibility of being a "French man" without being a "French citizen", see Silyane Larcher, L'Autre citoyen. L'Idéal républicain et les Antilles après l'esclavage (Paris, 2014), pp. I63-65.

I I. For instance, in 1789 , Martinique counted roughly 99, I00 inhabitants, for a surface of I, I 28 $\mathrm{km}^{2}$, in other words, eighty-eight inhabitants per $\mathrm{km}^{2}$. See J.H. Galloway, The Sugar Cane Industry: An Historical Geography from Its Origins to 1914 (Cambridge, 2005), p. I I 4.

I 2. Paul Butel, Histoire des Antilles françaises (Paris, 2003).

I 3. Nicolas Rey, Lakou et ghetto. Les quartiers périphériques aux Antilles françaises (Paris, 200I), pp. 54-57.

14. See the map of Saint-Pierre, I824, by M. Monnier. Available at: http://gallica.bnf.fr/ark:/ I 2 I $48 /$ btvi $1667004 \mathrm{I} 6 \mathrm{~m} /$ f7.item.zoom; last accessed I0 January 2017.

I 5. Rey, Lakou et ghetto, p. 56.

I6. Due to the carceral nature of the town of Saint-Laurent-du-Maroni in French Guyana and its specific development in relation to the prison, it will not be included in this study. On the difficulty of settling in French Guyana, see Marie-Louise Marchand-Thébault, “L’esclavage en Guyane française sous l'ancien régime”, Revue française d'histoire d'outre-mer, 47:166 (I960), pp. 5-75. 


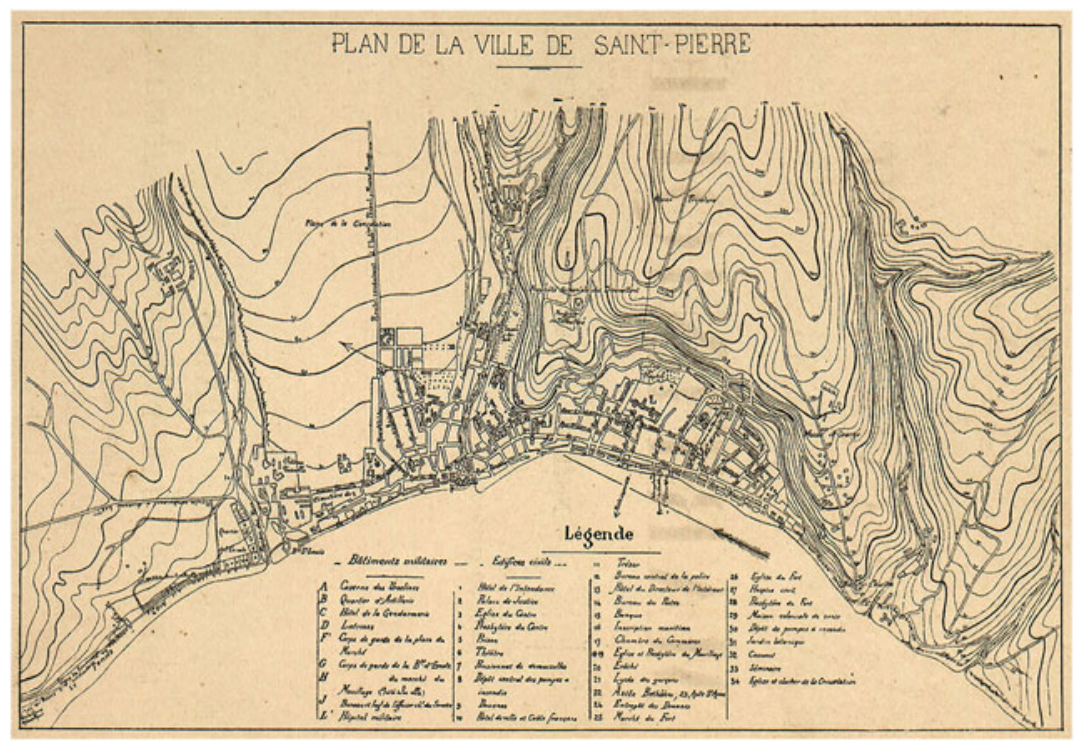

Figure I. Map of Saint-Pierre, Martinique, 1902.

dotted along the coast. ${ }^{17}$ Transport connections between the parishes in Martinique were relatively well established and frequent, but the geographical landscape of Guadeloupe made travel between the two sides of the island more difficult. The development of Pointe-à-Pitre, as a link between Basse-Terre and Grande-Terre, really started only with the British occupation of the island during the Seven Year's War. Drainage of the swampy grounds was necessary before any settlement was made possible. ${ }^{18}$ The distinction between urban and rural was sharpened in the French Antillean colonies: ${ }^{19}$ the model of economic development followed in Martinique and Guadeloupe meant that most of the workforce was spread in the rural areas to cultivate and harvest crops. The urban centres provided seats for the governmental, military, and judicial institutions, as well as some forms of entertainment for the elite and, for some, a place of residence. The number of inhabitants in the countryside was therefore much higher than in the urban centres, with an important concentration of slaves. Urban slavery may have

17. See, for instance, the map of Martinique in 1848 , in Gilbert Pago, Les femmes et la liquidation du système esclavagiste à la Martinique, I848-I852 (Matoury, I998), p. 20.

I8. Rey, Lakou et ghetto, p. 55 .

19. Malcolm Cross, Urbanization and Urban Growth in the Caribbean: An Essay on Social Change in Dependent Societies (Cambridge, 1979), p. 25. 
been more limited than in the rural areas, but it did exist: ${ }^{20}$ domestics, ${ }^{21}$ laundresses, and day labourers lived in the urban centres or in their immediate proximity and were more numerous than the white population. The rest of the white planters resided on their plantations, the habitations sucrerie, which started to decline in the second half of the nineteenth century. ${ }^{22}$

The main towns in the French Caribbean were located on the largest French islands: Martinique (Figure 2) and Guadeloupe (Figure 3), which, after the Napoleonic episode and an English invasion, continued to be governed by the French. Martinique was the official centre of the French Antilles, with the governor residing in Fort-Royal since 1790. Both Guadeloupe and Martinique's economies turned towards the production of sugar in the seventeenth century and the labour-intensive monoculture of sugar cane had a strong impact on the demographics of the islands: sixty to seventy per cent of the population were still working in the rural areas by the mid-nineteenth century. ${ }^{23}$ The urban centres of Saint-Pierre, Fort-Royal, ${ }^{24}$ and those of Basse-Terre and Pointe-à-Pitre developed thanks to the colonial economy and the importance of maritime trade. ${ }^{25}$ The population living in what can be defined as villes et bourgs was therefore rather limited: twenty-three per cent of the inhabitants of Guadeloupe (without dependencies) lived in a town or large village in 1847 ; in Martinique this was 26.5 per cent. White people accounted for eight per cent of the total population in Martinique in I 847 . The administration of Guadeloupe claimed that they could not give a precise number for the "white/coloured" ratio in I 847 but assumed it to be the same as in Martinique, and claimed that the class of freemen/freewomen was four times higher than the white class. ${ }^{26}$ A further note in I 849 explained that white people constituted one-twelfth, or 8.3 per cent, of the total population. ${ }^{27}$

20. Anne Pérotin-Dumon, La ville aux îles, la ville dans l'âle (Paris, 2002), p. $55 \mathrm{I}$.

21. Bernard Moitt, Women and Slavery in the French Antilles, 1635-1848 (Bloomington, IN, 200I), pp. 6I-62.

22. Christian Schnakenbourg, "La disparition des 'habitation-sucreries' en Guadeloupe (I 848 1906). Recherche sur la désagrégation des structures préindustrielles de la production sucrière antillaise après l'abolition de l'esclavage', Revue française d'histoire d'outre-mer, 74:276 (I987), pp. 257-309.

23. Myriam Cottias, "Droit, justice et dépendance dans le Antilles françaises (1848-1852)", Annales. Histoire, sciences sociales, 59 (2004), pp. 547-567, 548.

24. Roughly 24,000 inhabitants in Saint-Pierre in 1850 and $\mathrm{I} 3, \mathrm{I} 30$ inhabitants in Fort-de-France in I 853: Des villages de Cassini aux communes d'aujourd'hui. Available at: http://cassini.ehess.fr/ cassini/fr/html/I_navigation.php; last accessed I8 December 2019.

25. In 1 846, Basse-Terre and its suburbs counted 6,800 inhabitants; Pointe-à-Pitre and suburbs I 3,300 inhabitants according to Tableaux de population, de culture, de commerce et de navigation (Paris, I 846), p. I 5 . Note that Pointe-à-Pitre was badly destroyed in I 843 after an earthquake that killed an estimated 3,000 people.

26. Tableaux de population, de culture, de commerce et de navigation (Paris, I 85 I), pp. I 2-I 5.

27. Tableaux de population, de culture, de commerce et de navigation (Paris, I 852 ), pp. I4-I 5. 


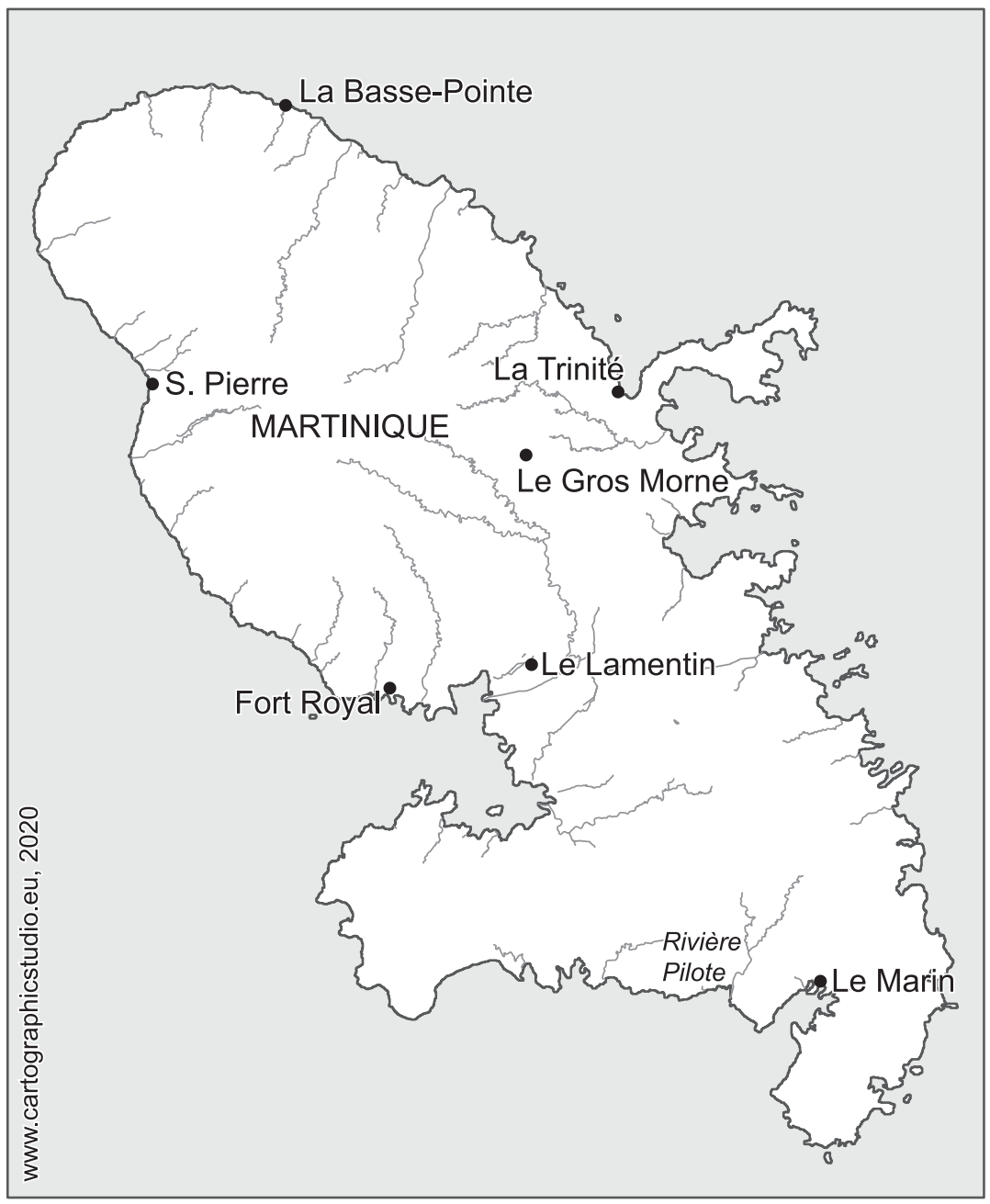

Figure 2. Map of Martinique and its main towns and villages, I 835 .

The urban centres (the bourgs, large villages, and towns) of the French Antilles were dominated thus by the free population consisting of the white elite (comprising settlers, or colons, and creoles), poor whites, the mixed-races, foreigners, and black freemen and freewomen. ${ }^{28}$ In Martinique before the abolition, the villes et bourgs counted around 23,800 free people and 8,200 slaves. In Guadeloupe and its dependencies, 19,500 free people and ı०,000 slaves lived

28. This category includes free-born blacks and freedmen and freedwomen. 


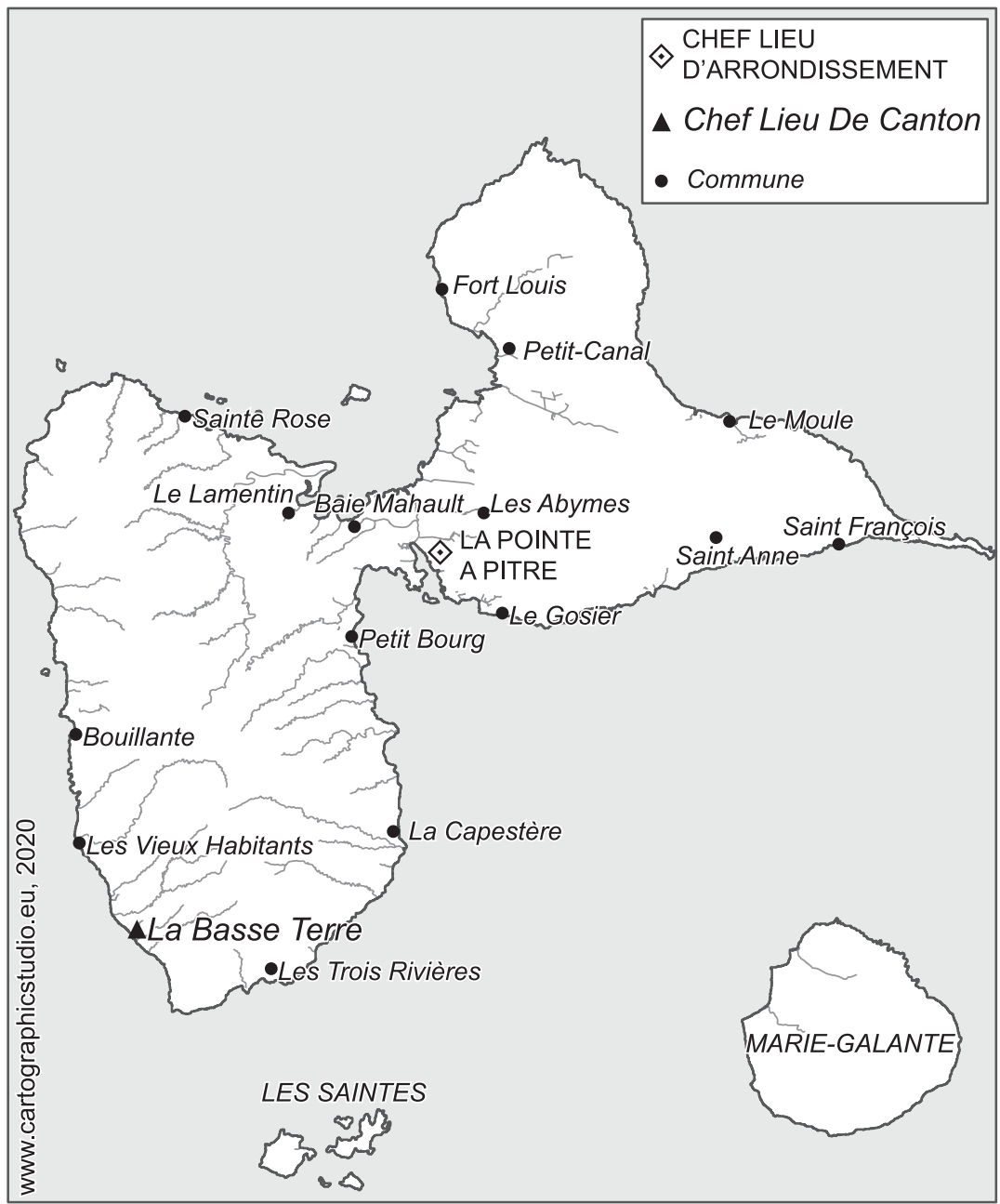

Figure 3. Map of Guadeloupe, based on an etching by Morin, I 835 .

in the towns and large villages. In contrast, rural Martinique had 24,400 free people and 64,600 slaves in 1846, while Guadeloupe had a larger share of slaves, with around 77,800 slaves and $2 \mathrm{I}, 800$ free people (Table I). ${ }^{29}$ The settlement of the official colonial government in the urban centres also brought with it a certain number of metropolitan civil servants and officials who resided close to the seat of the government. Many white colon families settled in these towns, but also freed blacks who had been manumitted and left their

29. Tableaux de population, de culture, de commerce et de navigation (Paris, I 85 I), pp. I2-I 5. 
Table I. Urban population in Martinique and Guadeloupe in the midnineteenth century.

\begin{tabular}{lccc}
\hline Islands & $\begin{array}{c}\text { Urban population } \\
\text { in } 1847\end{array}$ & $\begin{array}{c}\text { Rural population } \\
\text { in } 1847\end{array}$ & $\begin{array}{c}\text { Total population } \\
\text { in } 1847\end{array}$ \\
\hline Martinique & Slaves: 8,210 & Slaves: 64,640 & 121,130 \\
& Free: 23,861 & Free: 24,410 & \\
Guadeloupe & $26.5 \%$ & $73.5 \%$ & 129,109 \\
& Slaves: 9,975 & Slaves: 77,777 & \\
& Free: 19,528 & Free: 21,829 & \\
& $23 \%$ & $77 \%$ & \\
\hline
\end{tabular}

Source: Tableaux de population, de culture, de commerce et de navigation (Paris, 1851), pp. $12-15$.

former masters to work in towns. ${ }^{30}$ Before 1848 , slaves formed seventy-five per cent of the population in the French Antilles ${ }^{31}$ and although most of them were employed in the plantations, some were living in the towns as domestics for white and freemen's families, and they could also be seen working in the ateliers adjoining the port. ${ }^{32}$ According to the 1847 census in Guadeloupe, sixty-five per cent of urban families had between one and three slaves working in their household, most of them women, employed to cook, wash, and generally run the house. ${ }^{33}$ A list of 2 I 8 slaves from the French Caribbean colonies and La Réunion, whose slaves received their freedom in I 847, gives an example of the role of urban domesticity in slaves' occupations. Domestics counted for roughly forty per cent of the occupations of the urban slaves, along with manual labouring and working as a field hand, a much higher percentage than in the countryside. ${ }^{34}$ At the beginning of the nineteenth century, some urban slaves were also employed as day labourers and were hired out by their masters and mistresses (notably impoverished creole women) $)^{35}$ who were living in town. ${ }^{36}$ Overall, the ratio of "whites" to "people of colour" was therefore less disproportionate in the urban centres than in the countryside, especially on the sites of original settlement, which

30. Butel, Histoire des Antilles françaises, p. 307.

3. For Guadeloupe, see Pérotin-Dumon, La ville aux îles, pp. 330-33 I. For Martinique, see Arlette Gautier, "Les Familles Esclaves Aux Antilles Françaises, 1635-I848." Population, 55 (2000), pp. 975-I00I, p. 98 I.

32. Josette Fallope, "Les occupations d'esclaves à la Guadeloupe dans la première moitié du XIXe siècle”, Revue française d'bistoire d'outre-mer, 74:275 (1987), pp. I89-205.

33. Raymond Boutin, Petit-Canal. Une commune de la Guadeloupe au XIXe siècle (Paris, 1983).

34. Moitt, Women and Slavery, p. 6r.

35. Pago, Les femmes et la liquidation du système esclavagiste, pp. 36-37.

36. Rebecca Hartkopf Schloss, Sweet Liberty: The Final Days of Slavery in Martinique (Philadelphia, PA, 2009), p. I I. 
were the richest and best built. ${ }^{37}$ Before the abolition of slavery, the demography of the towns changed little, although the first half of the nineteenth century saw an increase of freedmen and freedwomen moving to the towns, linking urban development with the increase of free people. ${ }^{38}$

\section{“BEING MOBILE” IN THE FRENCH COLONIES}

Following the expansion of the colonial society from the seventeenth century, the socio-economic positions and the mobility (both social and spatial) of people inhabiting the Antillean islands were strongly defined by their colour, gender, and civil status. ${ }^{39}$ How one was to behave would depend on these criteria and going against prescribed behaviours, such as being absent from the master's house for too long or not taking care of one's family, would lead to various punishments for both white and black people. ${ }^{4}$ These could include fines, being shunned by the community, and even official expulsion from the colony. ${ }^{4 \mathrm{I}}$ However, slaves and freemen and freewomen had to endure much harsher punishments than white people, rich or poor. Slaves were regularly whipped and sometimes tortured for bad behaviour against their masters or against another white person. The society was strictly divided and people who did not belong to the two well-defined categories of black slaves or white elite often struggled to find their place and, more importantly, their rights in this colonial society. Black freemen and freewomen, mixed-race children and adults, and poor white people, also known as petit-blancs, were constantly negotiating their position in society, in relation to each other and under the control of the elite.

Despite these strict divides between classes, members of the free black and slave classes experienced a degree of social and spatial mobility before the abolition; and opportunities for mobility could often be found in the urban centres. Since the eighteenth century, some masters ignored the colonial legislation regarding slaves' work and freedom of movement by giving them substantial responsibilities in their business or by letting them carry out tasks away from the master's household and with little supervision. Indeed, in order to maximize their assets, some masters provided their slaves with an education and allowed them to keep small shops or take care of the accounts, or even gave them "managerial" responsibilities that, according to Coquille, the procurer of Guadeloupe, made them particularly "arrogant". ${ }^{42}$

37. For instance, the parish of the Fort in Saint-Pierre, which contrasted strongly with its poorer faubourgs. Or the poor district of Terres-de-Sainville in Fort-Royal, which grew after I 832.

38. Pérotin-Dumon, La ville aux îles, pp. 330-332.

39. Hartkopf Schloss, Sweet Liberty, p. I 16.

40. Ibid.

4I. Ibid., pp. I I7-I I9.

42. Pérotin-Dumon, La ville aux îles, p. 663. 
In receiving permission to rent a room in town as long as they share their wages with their master, the comings and goings of slaves in the urban environment were a common sight. Their role in the urban merchant economy was thus clearly visible. Some slaves were free to sail between villages to sell their master's products; one was trained as a jeweller and permitted by his master to roam the colony. ${ }^{43}$ The attitude of the masters towards marronage during the ancien régime sheds a similar light on the mobility of slaves: marronage was considered a problem only when slaves deserted in groups and formed "gangs", thus becoming a threat to the general order. Petit marronage, defined as the absence of a single individual or very small group for a few days, was often treated casually by the planter or his manager. ${ }^{44}$ Likewise, the punishment for a long period of time spent away from the plantation was contingent on the amount of time the slaves had already spent on the island: a newcomer accused of marronage was less likely to be branded than a slave who had already had the opportunity to build a network in and outside the plantation. ${ }^{45}$ This led to situations where maroon slaves were only reported missing after a few weeks or even a couple of months. ${ }^{46}$ Price notes that creole maroons were more likely to run away to the cities, where they knew they would be less likely to be questioned about their whereabouts, being surrounded by other people of colour, freemen, and freewomen, but also slaves, and thus experiencing a certain freedom of movement. ${ }^{47}$

Thus, the economic interests of planters encouraged a certain mobility of slaves to and from the urban centres. But the judicial system also unwittingly aided the connection between rural areas and urban centres by pushing certain victims to seek justice against their master in urban institutions. The slavery system led to the development of a particularly cruel private justice in the hands of the white masters. Slaves brought to or born in the French colonies were subject to the Code Noir, implemented in I 685 by Jean-Baptiste Colbert. The Code Noir was meant to cover the possession, transaction, and legal status of slaves in the French colonies. One of its paradoxes resided in the legal status of a slave; whereas they were considered movable possessions (for instance they could be inherited by the children of their owner), they were still legally responsible if they committed a crime..$^{4}$ This situation meant that they could be tried by the judicial system in place in the colony and sent to prison: this

43. Archives Nationales d'Outre-Mer (ANOM), Dépôt des fortifications des colonies, I 30 ; Pérotin-Dumon, La ville aux îles, pp. 663-666; S. Larcher, L'Autre citoyen, pp. 93-94.

44. Richard Price, Maroon Societies: Rebel Slaves Communities in the Americas, $3 \mathrm{rd}$ edn (Baltimore, MD, I996), pp. i I I-I I 2.

45. Price, Maroon Societies, p. I I 4.

46. Pérotin-Dumon, La ville aux îles, pp. 875-876; Moitt, Women and Slavery, p. I60.

47. Price, Maroon Societies, I 25.

48. Frédéric Charlin, "La condition juridique de l'esclave sous la Monarchie de Juillet", Droits, $52: 2$ (2010), pp. $45-74,63$. 
sentence had a direct impact on the owner of the slave, as he was losing for a certain amount of time a member of his workforce. To counteract this loss of revenue, the colonial system developed specific regulations concerning punishment, which allowed the master to punish them privately. ${ }^{49}$

Although most cases of mutilations and violence by owners went unpunished, a small number of slaves succeeded in getting their master condemned for excessive punishments. ${ }^{\circ}$ This was made possible by the fact that slaves had a legal identity even if they were considered movable possessions. Therefore, they could access the court of justice to seek reparation. The courts of justice in the colonies were located in the urban centres and gaining access to them could be difficult if the slaves were not allowed to leave the property. However the number of freemen and freewomen had increased since the eighteenth century and they could serve as intermediaries with officials to transfer the slaves' complaints or to help them buy their freedom. ${ }^{\text {I }}$ Slaves could benefit - after the imposition of the Penal Code in I 828 - from the pourvoi en cassation (appeal to have the legality of a judgment assessed by the highest judicial court in Paris) if they were involved in the same criminal affair as a freeman or freewoman; by I 838 they could do it by themselves. ${ }^{52}$ Thus, a network of information and assistance was created between rural slaves, rural freemen and freewomen, and the urban environment, and this network was strengthened by their meetings during balls, festivities, and urban processions. ${ }^{53}$ Unwittingly, the flawed colonial justice system in Martinique and Guadeloupe helped create links between people from the lower classes, which then produced networks of information about rural and urban concerns. Likewise, the relative mobility between plantations and the urban environment afforded to certain slaves helped facilitate the exchange of political news from other countries and the metropole. ${ }^{54}$ Urban domestics who heard and repeated their masters' discussions during dinner were often complained about by officials, especially in times of rebellion. ${ }^{55}$ As such, the links between slaves, former

49. For instance, see Pago, Les femmes et la liquidation du système esclavagiste, pp. 39-42.

50. John Savage, "Between Colonial Fact and French Law: Slave Poisoners and the Provostial Court in Restoration-Era Martinique”, French Historical Studies, 29:4 (2006), pp. 565-594, 570-71; Price, Maroon Societies, p. I I 4.

51. Anne Pérotin-Dumon, Etre patriote sous les Tropiques (Basse-Terre, 1985); Pérotin-Dumon, La ville aux îles, pp. 877-878.

52. Collection complète des lois, décrets d'intérêt général, traités internationaux, arrêtés, circulaires, instructions, etc., vol. 35 (Paris, I836), p. I49; Crim. I7 août I838, Bulletins Criminels, no. 43, p. 405 , v. annexes, no. 3, quoted in Charlin, "La condition juridique de l'esclave", p. 64, n. 87; R. Montgomery Martin (ed.), The Colonial Magazine and Commercial-Maritime Journal, vol. I (London, January-April i 840), p. 465.

53. Larcher, L'Esclave et le citoyen, p. 94.

54. Julian S. Scott, "The Common Wind: Currents of Afro-American Communication in the Era of the Haitian Revolution" (Ph.D., Duke University, 1986), pp. 34-35.

55. Larcher, L'Esclave et le citoyen, p. гог. 
slaves, and pro-abolitionist white people were strengthened thanks to the judicial identity of the slaves and the economic possibilities of the towns, this dynamic being most visible in the urban environment where contact between people of different backgrounds was regularly observed.

\section{POPULATION CONTROL AND RESTRICTED MOBILITY IN THE NINETEENTH CENTURY}

The question of mobility became particularly conspicuous after the abolition of slavery in I 848 , when the codes that regulated the travelling and movement of people (for instance the sale of a slave to another planter) officially disappeared. The abolition brought a new legal and social status to the former slaves: more than I62,000 inhabitants of Martinique and Guadeloupe became freemen and freewomen and French citizens, now deserving of treatment equal to that of white French citizens. ${ }^{56}$ With the abolition of slavery, every citizen was given the right to travel throughout the colony, as long as he or she could prove a place of residence and means of subsistence. This meant that citizens should have been allowed to settle where they wished, also in the urban areas. The reality was very different, however. Historians have shown that the white elite in French plantation colonies refused for a long time to submit to legal and judicial changes imposed by the metropole. ${ }^{57}$ There are several reasons for this. First, the white elite feared a loss of power and identity. Second, they were afraid of losing the opportunity to punish their slaves privately; up until that point the responsibility of punishing slaves had been controlled by private justice. In reality, restrictions on mobility had already begun after the return of slavery in 1802 . Access to urban areas became more and more restricted after the Napoleonic wars with the development of vagrancy laws and an increased police and militia presence in both towns and the countryside. Indeed, the nineteenth century changed the dynamic at play during the ancien régime, with the creation of a "slave police" after the reinstatement of slavery in the colonies in I 802. Police commissaires were appointed in every town and were charged with keeping the peace and forcing ex-slaves to return to their masters..$^{8}$ Officials focused on urban areas in order to limit the apparent freedom enjoyed by certain slaves and frustrate their attempts to pass as freemen and freewomen in the urban economy.

56. Jean-Pierre Sainton, “De l'état d'esclave à 'l'état de citoyen'. Modalités du passage de l'esclavage à la citoyenneté aux Antilles françaises sous la Seconde République (1848-1850)', Outre-mers, 90:338 (2003), pp. 47-82, 53 .

57. John Savage, "Unwanted Slaves: The Punishment of Transportation and the Making of Legal Subjects in Early Nineteenth-Century Martinique”, Citizenship Studies, I0: I (2006), pp. 35-53; Savage, "Between Colonial Fact and French Law"; Hartkopf Schloss, Sweet Liberty.

58. Pérotin-Dumon, La ville aux îles, p. 668. 
During the discussions that preceded the abolition of slavery, the commission for the abolition of slavery, presided by Victor Schoelcher, advised the Ministère de la Marine et des Colonies (Ministry of the Navy and Colonies) to implement new legislation against vagrancy to prevent former slaves leaving for another planter. ${ }^{99}$ The influence of the British colonies is perceptible in Schoelcher's legal provisions: in Barbados, for instance, during the apprenticeship period, vagrancy laws were designed to prevent "idleness" and used to complicate the search for a new job by former slaves. Former slaves were forced to stay in the countryside to work for their former masters to avoid arrest. The vagrancy laws in the British islands in the 1830 s formed part of the white attempt to prolong the plantation system and sustain its economic development despite the abolition of slave labour. ${ }^{60}$ In the French islands of Martinique and Guadeloupe, where economic resources were also based on the plantation system, preventing the new French citizens from leaving the countryside also became a necessity for the creoles. The abolition of slavery on 27 April I 848 led to a modification of the legal system in the Antillean colonies regarding mobility and the right to work: in order to maintain and eventually reinforce their governmental powers, local authorities quickly imposed new regulations on the movement of the new French citizens. The plantation system suffered economically and politically: the migration of former slaves to the urban centres (Saint-Pierre and Fort-de-France in Martinique, Pointe-àPitre and Basse-Terre in Guadeloupe) destabilized the system of private justice as much as their newly acquired freedom. In July and August I 848, various decrees were published to prevent vagrancy and idleness. The definition of vagrant was very broad: it included people who had no precise address; those who had a home but no job; those who were eating in someone else's house; those who built an ajoupa (a cabin or wooden shack); and those who had temporary employment but no home. ${ }^{61}$ In order to tighten control of the population, the authorities encouraged the development of a (rural) police force to patrol the colonies. ${ }^{62}$ In addition to this police force, the governor of Guadeloupe encouraged the use of militia constituted by citizens, "to protect people and property" and specifically to arrest vagrants. ${ }^{63}$ The militia was meant to "forget all distinctions of origins", however Schoelcher himself, during the first elections organized around universal suffrage in I 849 , denounced

59. Recueil de la législation nouvelle (Basse-Terre, I 848), p. 8.

60. Anthony de V. Philips, "Emancipation Betrayed: Social Control Legislation in the British Caribbean (with Special Reference to Barbados), I834-1876 - Freedom: Beyond the USA", Chicago-Kent Law Review, 70 (1995), pp. I349-I 372.

6I. Josette Fallope, Esclaves et citoyens. Les noirs a la Guadeloupe au XIXe siècle dans le processus de resistance et d'integration (I802-I9IO) (Basse-Terre, I992), p. 400.

62. Adolphe Gatine, Abolition de l'esclavage à la Guadeloupe: Quatre mois de gouvernement dans cette colonie (Paris, 1849), pp. $65-66$.

63. Ibid., p. 65 . 
the discrimination suffered by black people at the hands of the militia and gendarmerie. They did not hesitate to shoot black citizens who tried to free a man unjustly accused. ${ }^{64}$ This was followed in February I 852 by the creation of the livret de travail (work pass) for labourers employed for less than a year, and new restrictions "to combat vagrancy". 65 Eventually, on io September I 855 , the governor of Martinique Louis Henri de Gueydon passed an edict making it compulsory to have a passport to move between parishes for everyone over sixteen years old. ${ }^{66}$ This local legislation, published under the title Police $d u$ travail, went against the French rules of free movement but it was not until I 870 that its repeal became a subject of discussion in the assembly. ${ }^{67}$

The increase in prosecutions against "vagrants" was not, in itself, unique to the colonies. Parallel to the bureaucratization and professionalization of the police system at the beginning of the nineteenth century (in the city but also in the countryside with the gendarmerie), a more efficient control of the population was imposed by officials from the metropole. The prosecution of vagrancy was defined by Article 270 of the I 8 ro Penal Code as being without a permanent address, travelling with no means of subsistence, and having no regular employment. It became an offence (délit) to be tried by the Tribunal of First Instance. ${ }^{68}$ This legislation was officially applied in the Caribbean colonies in $1828 .{ }^{69}$ However, as Philips has shown in the case of Barbados, where the vagrancy laws in place followed the wording of their British domestic counterparts but had very different purposes, ${ }^{70}$ the practice of the law was much more radical in Martinique and Guadeloupe than in the metropole. The Antillean colonies could still be ruled by gubernatorial decrees and had therefore developed specific legislation on labour and vagrancy, in place until i 878. Although in the judicial archives we see an attempt by the clerk to delete any form of discrimination by not mentioning the colour or (ex-) civil status of the suspect, it becomes obvious that the law was discriminatory in practice. Indeed, in the duplicates of sentencing papers sent to Paris, the mention of colour or origins (mulatto, "mixed-race"; capresse, child born from a mixed-race person and a black person) disappeared, giving the

64. Victor Schoelcher, quoted in Bulletin colonial. Supplément à la revue du XIXe siècle (Paris, I 849$)$, n.p.

65. Butel, Histoire des Antilles françaises, p. 308; Bruno Maillard, “'Ils sortiront des hommes'. Les enfants du pénitencier de l'Ilet à Guillaume (île de la Réunion) I 864-I879”, Criminocorpus. Revue bypermédia. Available at: http://criminocorpus.revues.org/1770; last accessed I 2 June 2017.

66. Anne Girollet, Victor Schoelcher. Abolitionniste et républicain (Paris, 2000), pp. 266-267.

67. Victor Schoelcher, L'arrêté Gueydon à la Martinique et l'arrêté Husson à la Guadeloupe (Paris, I 872).

68. Available at: http://ledroitcriminel.fr/la_legislation_criminelle/anciens_textes/code_penal_ı 8 Io/ code_penal_I8IO_2.htm; last accessed I3 June 2017.

69. Recueil d'ordonnances royales concernant la Guadeloupe, I824-I828, vol. 2, pp. 72-73. Available at: https://issuu.com/scduag/docs/adg I 8 I 54-2/73; last accessed 8 November 2019.

70. Philips, "Emancipation Betrayed". 
impression that the suspects were treated equally. In reality, numerous former slaves did not have a surname and were still registered without one, giving away their origins. ${ }^{7 \mathrm{I}}$ The judicial archives thus show the specific focus set by the administration on these former slaves. It is interesting indeed to see that, except in two cases, the vagrancy cases brought to the court only concerned black people. ${ }^{72}$

In the early months after abolition, the number of vagrants arrested by the gendarmerie was still relatively low: in August I 848, in Guadeloupe, only six vagrants among fifty-eight suspects were arrested, and at the end of the year, an average of fifteen prisoners were sent to the ateliers de discipline (type of forced labour). ${ }^{73}$ In the session of January i 85 I of the Guadeloupe Court of Appeal, ten cases referred to the délit of vagrancy. ${ }^{74}$ It appears, however, that all of the suspects arrested for vagrancy could give an address where they lived and slept. By definition, they were therefore not vagrants but had come to town to look for work. For instance, Marcelin, a young carpenter apprentice, was born in Les Anses d'Arlet in the south of the island but came to Saint-Pierre to find employment: ${ }^{75}$ as he was paid by the task, his work migration was legitimate and even if he had meagre resources, he could not, if they were to follow the wording of the original Penal Code, be considered a vagrant. He was, however, arrested when he decided to settle in the old town of Saint-Pierre to look for work. Multiple accounts reveal similar experiences in the years following abolition; the suspects gave their place of birth and residence but were still tried for vagrancy due to the fact that they were moving and walking within the region, searching for employment.

In the first semester of 1855 , in Saint-Pierre, out of ninety-one cases tried in the Tribunal of First Instance, thirty-two were related to accusations of vagrancy (twenty men and twelve women).$^{76}$ Julie's case is representative of the treatment received by "vagrants". She was born in Africa and lived in Grand'Rivière, working as a faiseuse de bouts (cigarette maker), but was arrested in Saint-Pierre while at work. She was then sentenced to six months in prison, the usual sentence in Martinique against vagrancy, whereas the Penal Code required a three-to-six-month sentence. ${ }^{77} \mathrm{Had}$ she been a man she would have been sent to work on the public roads or sent to an atelier

7I. Certain former slaves were registered in the état civil (registry office) up to fifteen years after the abolition of slavery. See Larcher, L'Autre citoyen, p. I9I; Guillaume Durand, 'Spécificités anthroponymiques Antillaises. Les noms de famille des Martiniquais d'ascendance servile', Nouvelle revue d'onomastique, 39-40 (2002), pp. 307-329.

72. ANOM, 6DPPC/I I5.

73. Ibid., pp. 67-68.

74. Gazette officielle de la Guadeloupe, 20 February i 85 I, pp. I-3.

75. ANOM, 6DPPC/i is.

76. Ibid.

77. Ibid. 
de discipline, which were created to put vagrants to work. ${ }^{78}$ Five ateliers de discipline were created in Guadeloupe: two in Basse-Terre and Pointe-à-Pitre and three others in the islands of Saintes, Saint-Martin, and Marie-Galante, where urbanization was almost null. Prisoners were forced to do public work, often outside the urban enclaves, but they could also be sentenced to work for a planter.

The mobility and access to urban areas of former slaves were not only limited by vagrancy laws, but also by the restructuring of the judicial system. As we discussed previously, the way the judicial system worked during the ancien régime encouraged the development of links between rural and urban areas, essential to gaining access to official institutions. However, the reorganization of the judicial system that occurred in I 828 , with the imposition of the Code d'Instruction Criminelle and the Code Pénal, and the bureaucratization of the justice system from the Revolution onwards led to the creation of local courts (juges de paix and tribunal cantonal) in the more rural areas to deal with conflicts between employers and employees; in a similar fashion to the appointment of local commissaires, the judicial system was brought closer to the rural population, but it mostly benefited the white employers. Likewise, the existence of local courts prevented former slaves from going to the cities to seek redress as it was not possible to bypass the local judge, meaning that one very important reason to go to the city (to access formal institutions) became obsolete after $1789 .{ }^{79}$

Finally, the economic opportunities offered by the towns before abolition did not increase sufficiently to provide enough outlets for the newly freed population, at least according to the government. The fact that the economic resources of the islands remained the same in the three decades following abolition suggests that the planters did not take the opportunity to change their economic model. The culture of sugar cane continued - many former slaves were now being employed as day labourers. Urbanization continued to increase but at a relatively slow pace compared to European cities. ${ }^{80}$ Indeed, the new factories that opened for the transformation of the sugar cane economy were located close to the fields and did not encroach on the urban landscape. Thus, as various historians have shown, many socio-economic aspects of the pre-abolition Antillean society prevailed even after the abolition of slavery and the process of restraining citizens' mobility continued. ${ }^{8 \mathrm{r}}$

78. Gatine, Abolition de l'esclavage à la Guadeloupe, p. 66; Recueil de la législation nouvelle, p. 23; Nelly Schmidt, “г 848 dans les colonies françaises des Caraïbes. Ambitions républicaines et ordre colonial", Revue française d'histoire d'outre-mer, 85:320 (1998), pp. 33-69, 52-53.

79. Ministère de la Marine et des Colonies, Les colonies françaises en I 883 (Paris, I 883), pp. 36-40. 80. Tableaux de population, de culture, de commerce et de navigation (Paris, I846), p. I 2 for Martinique.

8I. Gilbert Pago, L'Insurrection du sud. Contribution à l'étude sociale de la Martinique (Fort-de-France, 1974), pp. 5-34; Nelly Schmidt, La France a-t-elle aboli l'esclavage? (Paris, 2009). 
Access to the urban environment during slavery was also linked to economic opportunities but the job market in the towns after abolition remained limited, agricultural labour still providing most of the employment. ${ }^{82}$ Skilled artisans were sought after, but most of the new citizens were unskilled labourers and many former slaves chose to become owners of their cabins and small gardens, if they were successful in gaining ownership from planters. Likewise, more than 2,000 cabins were said to have been built in the Guadeloupian countryside between I 848 and I 852, and in Rivière-Pilote in Martinique, on the slopes of the mountain, former slaves joined freemen and freewomen in cultivating vegetables for domestic and market consumption. ${ }^{83}$ In addition to the risk of being arrested as a vagrant, a heavy tax (impôt personnel) was imposed on each worker: fifteen francs per year for someone leaving a town, ten francs for a villager (living in a bourg), and five francs for a countryside inhabitant. This tax was initially imposed in I 846 in order to prevent the affranchis from leaving the plantations, where their labour was needed, and was increased in $1848 .^{84}$

The newly acquired freedom created fear in the white population (due to the large number of former slaves, the fear of riots and demands for redress, the reduction in employment opportunities as new workers entered the market) and the white elites actively blocked the migration and potential settlement of former slaves in the towns. Again, contradictory dynamics were at play in the practice of the law: on the one hand, freedom of movement had to be given to every citizen, as long as they could claim a residential address and employment (per task or per contract), but on the other hand, mobility towards the urban centres was strongly limited by the misuse of vagrancy laws in an attempt to prevent the loss of workforce on the plantations. Mobility from one plantation to another was not the main issue, however; when looking at the way the laws were used, it appears that it was mobility towards and settlement within the towns that were criminalized.

\section{WHITE TOWNS, BLACK COUNTRYSIDE?}

The white elite's efforts to hold back former slaves in the rural plantations through the strong use of vagrancy laws reveal another facet of their concerns, which was not directly linked to the possible loss of income. By strengthening the repression against "idle" or seemingly "vagrant" citizens (who did nevertheless have a place of residence), the elite also tried to limit the migration of former slaves to the urban enclaves. The cases brought to the judge of the

82. Rosamunde Renard, "Labour Relations in Martinique and Guadeloupe, i 848-1870", Journal of Caribbean History, 26:I (1992), pp. 37-6I, 39.

83. Fallope, Esclaves et citoyens, p. 4I 3; Larcher, L'Autre citoyen, p. 277.

84. Gatine, Abolition de l'esclavage à la Guadeloupe, p. 76. 
Tribunal of First Instance reveal a strong focus on former rural slaves crossing the "border" of the urban environment, the town and its faubourgs. The records that survive show mostly suspects arrested for vagrancy and idleness who were residing in rural areas but came to Saint-Pierre or Fort-de-France to find work. "Idle" men and women who were already living in town before the abolition were very rarely reported in these archives and if they were, they were likewise condemned to six months' imprisonment, in an atelier in the suburbs or even outside the city limits.

An interesting case was sent to the highest French judicial court, which shows the willingness of the local court to drop vagrancy charges if the suspect decided to settle on a plantation. In I 852 the cassation court in Paris broke the judgment of the appeal court of Martinique, which had dropped the case against Louis, suspected of vagrancy, who had agreed to work and live on Ducoulange's land. The cassation court claimed that Louis had indeed been in a state of vagrancy before Ducoulange's offer to work for him; therefore, the prosecution fees should not have been settled by the colony, nor should the case have been dropped. The state had the right to force Louis to carry out three months of public work, as defined by the laws of 1828 and I $848 .^{85}$ It seems that this case reveals divergent points of view on the role of regulated mobility in the colonies: whereas the local authorities were satisfied with Louis settling in the countryside to work and therefore dismissed the case against him, Parisian judges, less aware of the local situation, argued against dismissing the case.

The regulation of mobility after the abolition, however, reveals more than a simple concern over a potential lack of employees: sugar production levels in the years following the abolition did drop, but the period I 8 I 7 - I 882 remains a period of expansion for sugar export. Likewise, the production of secondary crops such as cotton, coffee, and cacao increased regularly after the abolition. ${ }^{86}$ The colonies were also aware of their need to develop a more industrialized production to compete with European beet sugar, and this many years before the abolition of slavery. ${ }^{87}$ This specific legislation on vagrancy and labour mirrors a more or less conscious attempt to limit access to the urban environment to the white, "deserving" population and prevent a rural exodus that would see the towns being taken over by former slaves. Indeed, the restrictions imposed upon black people were already seen in the treatment of freemen and freewomen before the abolition of slavery. A petition from "free men of colour",

85. Désiré Dalloz (ed.), Jurisprudence générale du royaume. Année I852, p. 32; see also Martine Fabre, "Le rôle de la Cour de cassation dans l'élaboration du droit colonial", Histoire de la justice, I6:I (2005), pp. $75-92$.

86. Fallope, Esclaves et citoyens, pp. 358-36r; Nelly Schmidt, "Les paradoxes du développement industriel des colonies françaises des Caraïbes pendant la seconde moitié du XIXe siècle, perspectives comparatives", Histoire, économie et société, 8 (1989), pp. 31 3-333, 327.

87. Schmidt, "Les paradoxes', p. 3 I4. 
merchants, and landowners, was sent to the French parliament in I 829 to complain about the fact that official positions in the French administration and in public office, generally located in the urban centres, were forbidden to them, in contradiction with what the old Code Noir prescribed (a freeman or freewomen would have the same right as a French citizen) ${ }^{88}$ Preventing access to administrative positions was a means of denying them access to the "white class" and to social mobility, but it also gave them an incentive to leave the town if they could not find employment.

The abolition of slavery and the disorder that ensued had a strong impact on planters' feeling of safety. The abolition brought hundreds of white planters to the cities. But the migration of planters to the towns in troubled times, and to Saint-Pierre in particular, is an odd reaction when compared to the first abolition of slavery in $\mathrm{I} 794$. The pro-abolitionist planters of Martinique addressed planters in the Antilles by claiming that the pro-abolitionist riots in Saint-Pierre since 1790 were misrepresented by the anti-abolitionist planters as a "war between the planters and the town of Saint-Pierre". ${ }^{89}$ The colonial assembly in Martinique, seated in Fort-Royal since 1790 and strongly antiabolitionist, argued that it was the people of the towns who wanted to establish equality, setting them up in opposition to the more practical people of the countryside. ${ }^{90}$ The cleavage between the planters and merchants and petitblancs of Saint-Pierre appeared patent in this pamphlet and certain officials played upon these dissensions to impose their views. A similar attempt by urban patriots in I789-1792 to abolish slavery was thwarted in Guadeloupe by the community of the rural elite. ${ }^{91}$ In February 183 I, a slave uprising aimed to torch and pillage the city of Saint-Pierre: cane fields were burned, planters' families were shipped to France or the United States for refuge, and a letter published in a French newspaper described Saint-Pierre as the "most miserable place on earth due to its succession of bankruptcies and interest rates of 50 per cent on loans". $9^{2}$ During this episode, planters' families did not reach Saint-Pierre to find refuge but instead escaped to the metropole or to foreign countries.

In the middle of the century, the discourse had changed, both in the words of the administration and of the elite. First, the tax mentioned above and imposed on urban inhabitants was meant to "drive away from the towns the inhabitants of the countryside". Likewise, small merchants and artisans had

88. Pétition des hommes de couleur de la Guadeloupe (Paris, I830).

89. Adresse des planteurs réfugiés dans la ville de St Pierre Martinique, aux Planteurs des Antilles (Saint-Pierre-Martinique, I790).

90. Jacques Adélaïde-Merlande, La Caraïbe et la Guyane au temps de la Révolution et de l'Empire, $1789-1804$ (Paris, I992), pp. 55-56.

9I. Frédéric Régent, "Révoltes, factions, catégories juridiques et sociales en Guadeloupe (17891794)", Cabiers d'histoire: Revue d'histoire critique, 94-95 (2005), pp. 87-99.

92. Moitt, Women and Slavery, pp. I30-I 3 I. 
to pay a specific tax to do their trade, in order to "reduce the number of parasitic and miserable industries carried out by the idle men who ran away from the cultivation of the land". ${ }^{93}$ The government was actively pushing away anyone who was not welcome in the cities. Second, by I 848 , the elite had developed a new understanding of the city: it appears that the creole elite sought help and refuge in the urbanized environment and their discourse about the urban environment changed dramatically. The written testimonies of rural planters who experienced slave riots demonstrate their logical search for help where the island official powers resided, in Saint-Pierre or Fort-deFrance, and at the same time reframed their view of the urban environment as a place of safety.

Irmisse de Lalung, a creole white planter and aristocrat living with her family in Le Prêcheur, wrote in her diary in 1848 :

We were expecting a serious event at Prêcheur; many scared women withdrew to Saint-Pierre. Our kin from the town asked us to join them; my uncle insisted that we moved $[\ldots]$ we were sorry not to have M. Dujon with us [...] his wife, frightened by the situation, forced him a few days before to take her to Saint-Pierre. ${ }^{94}$

In addition to seeking the support of the governor or influential officials, the white rural elite could also count on the presence of the militia and army, and the possibility, in extreme situations, to board a boat. To the elite, the towns came to represent the safest environment in a tense situation. Seeing the streets in these towns taken over by former slaves, who publicly showed their joy when slavery was abolished, was particularly despised and feared by the antiabolitionist elite:

From the edge of the ambush, we could see the town festivities [...] the negroes, who had taken all the horses, donkeys, and carts of their former masters, roamed the streets in cavalcade, insulting the whites. ${ }^{95}$

Dessalles, who opposed the abolition, wrote on 24 May I 848: "The streets are full of screaming and yelling negroes stopping passers-by and forcing them to shout 'Vive la République! Vive la liberté!". ${ }^{96}$

Various episodes of such violence were reported by pro-planter newspapers surrounding the 1849 elections: people of colour from Port-Louis were described as "cannibals willing to eat the flesh and drink the blood of

93. Fallope, Esclaves et citoyens, pp. 400-40I.

94. In “Notes sur les évènements du Prêcheur et émigration à Puerto Rico", Saint-Pierre, I 849; see ANOM, box I 53 , folder I275, quoted in Pago, Les femmes et la liquidation du système esclavagiste, p. I03. Unless otherwise stated, all quotations from French sources rendered in English are my translation. My translation.

95. Pago, Les femmes et la liquidation du système esclavagiste, p. I I4. My translation.

96. Pierre Dessalles, magistrate and Conseiller Supérieur of Martinique from I 808 to I 83 I, wrote a long diary recording his life in Martinique between I 808 and I 856 , quoted in Pago, Les femmes et la liquidation du système esclavagiste, p. I 13. 
Bissette". ${ }^{97}$ Similar rhetoric was used in a letter written by Bissette about the "mulâtres" 98 in Fort-de-France: "I know that there is in the town of Fort de France, more than one mulatto [...] who would like to see the heads of my children at the end of a spike". ${ }^{99}$ In Martinique, men of colour were chosen to sit in the administration of the two main cities in September I 848, but one year later the atmosphere had soured and pro-planters took back control of the government. Rumours circulated that the former slaves were trying to repeat what had happened in Saint-Domingue and the whites started to fear the "natural barbarity of Africans". ${ }^{100}$ The purging of the administrations, dissolution of (urban) political clubs, and stricter control over the black population thus followed. In Guadeloupe in March i 850 , after legal and administrative changes, only eight of the thirty-two mayors on the islands were of colour. ${ }^{\mathrm{IOI}}$ At the same time, a general fear of riots grew among the planters: politically engaged leaders of colour promised retribution to the former slaves, for instance in the village of Petit-Canal in Guadeloupe, the story of which is published in the Causes célèbres des colonies. ${ }^{102}$ In addition to violent threats against the planters heard in the countryside, some rural habitations of former masters were burned and white people were forced to flee to the main towns. ${ }^{103}$ Arson of planters' houses in the countryside was common until I 860 and the administration blamed these fires on the "malice" of the "creole workers", "indigenous workers", and other "autochthone workers". ${ }^{104}$ An anecdote related by the abolitionist Jean-Baptiste Colson reveals the tension that existed in the countryside at the time: while visiting the surroundings of Case-Pilote in Martinique, he came across a woman, a former slave, who asked him, a béqué, ${ }^{105}$ what he was doing there. When he asked for a glass of water, she told him to move on, sending him towards a house where she knew white people "like him" were still living. Colson explains that only thanks to the Republican symbols he was carrying and the egalitarian relations he had established from the start with the woman was he able to win her confidence and a glass of water. ${ }^{106}$ Many members of the rural elites were still antiabolition, and it is clear from this anecdote why they changed their views about the traditionally pro-abolition cities, moved to the urban areas for protection, and tried to prevent "the fall" of what they would consider their last bastions of power.

97. Bulletin colonial. Supplément à la revue du XIXe siècle (Paris, I849), n.p.

98. Mulâtre, "mulatto", mixed-race.

99. Bissette quoted in Bulletin colonial. Supplément à la revue du XIXe siècle (Paris, I 849), n.p.

Ioo. Fallope, Esclaves et citoyens, pp. 384-387.

Iог. Ibid., p. 386.

102. Causes célèbres des colonies, t. 2 affaire du petit/canal.

I03. Larcher, L'Autre citoyen, p. I75.

I04. ANOM, Martinique folder I $2 \mathrm{D}$ i 8.

105. Béqué or béké: descendant of the first colons and/or slave masters.

г06. Anecdote quoted in Larcher, L'Autre citoyen, pp. I79-г 8 I. 


\section{CONCLUSION}

Urban slavery in the largest French Caribbean islands remained limited due to the fact that the agricultural land needed most work from the men and women. The towns were inhabited by the government elite, some white artisans, and many freemen and freewomen who participated in the development of the port and took advantage of the comings and goings of crews and goods. The slaves who lived in the towns were employed in domestic tasks within the household of a white or black family. Even if the number of urban slaves was limited, seeing rural slaves walking the urban streets was not a rare phenomenon. They would be sent to the nearest town by their owner to carry out certain tasks and had, if they were not runaway slaves, relatively easy access to the town, within the limits set by their owner. The nineteenth century and especially the abolition of slavery changed this dynamic: journeys that were once allowed and irregularly checked became a threat to both the town and rural elites, who feared losing their plantation workforce, their legal supremacy, and their access to the best positions. The elites, to which the magistrates presiding in the Tribunal of First Instance belonged, quickly responded to this "unchecked" mobility of the new citizens of the colonies. They misused the racially neutral legislation of the Penal Code on vagrancy to limit the mobility of former slaves towards the towns. In the metropolitan cities, vagrancy laws had the double aim of enforcing strict control of the population, while allowing and securing free movement of the "respectable/controlled population" (people who had a permanent address and means of survival). The practice of the law in the colonies, however, went against the movement of a certain category of people, who were deemed undesirable in the towns but were needed in the rural areas. The fact that they had a place of residence did not prevent them from being arrested and tried. As such, the decrees relative to the colonies and eventually the Penal Code itself became economic and migratory tools in the hands of the creole elite whose main economic resources were the plantation system and export of colonial products. The fear of losing income in an already struggling economy forced officials to find new ways to control the newly freed population and prevent their settling in more urbanized areas, especially if their hands and skills were not needed.

The towns thus became sites of contestation between the white elite and people of colour; the creoles did their utmost to keep these urban enclaves from growing even further. By twisting the meaning of the law, the elite succeeded in creating invisible barriers to the urban landscape in order to preserve it, as much as possible, as a "safe haven", controlled and inhabited by white people, leading the way to unwritten forms of segregation. 